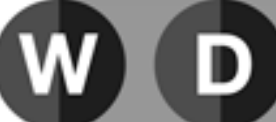

William Davidson Institute

AT THE UNIVERSITY OF MICHIGAN

\title{
ECONOMIC (IN)SECURITY AND GENDER DIFFERENCES IN TRADE POLICY ATTITUDES
}

\author{
By: Jeffrey Drope and Abdur Chowdhury
}

William Davidson Institute Working Paper Number 1067

January 2014 


\author{
Jeffrey Drope \\ Department of Political Science \\ Marquette University \\ and \\ American Cancer Society, Atlanta, GA \\ jeffrey.drope@marquette.edu \\ Abdur Chowdhury \\ Department of Economics \\ Marquette University \\ abdur.chowdhury@marquette.edu
}




\title{
ECONOMIC (IN)SECURITY AND GENDER DIFFERENCES IN TRADE POLICY ATTITUDES
}

\begin{abstract}
Over time and across countries, researchers have noted frequent and mostly unexplained gender differences in the levels of support for policies of free or freer trade: women tend to be less favorable toward policies of liberalizing trade than men. Using an economic security explanation based principally on a mobile factors approach, we find that is not women generally who are more negative toward trade but particularly economically vulnerable women - i.e. women from the scarce labor factor. We utilize recent survey data on individuals' attitudes toward different facets of trade and its effects across three disparate regions to examine this phenomenon empirically. An economic security approach helps to explain the marked differences in attitudes toward trade among lowerand higher-skilled females in developing and developed countries.
\end{abstract}

Key words: trade policy, gender difference, labor mobility, Latin America, Muslim countries

JEL Classification: F14, F20, O57 


\section{Introduction}

Over time and across countries, researchers have noted frequent and mostly unexplained gender differences in the levels of support for policies of free or freer trade: women tend to be less favorable toward policies of liberalizing trade than men (e.g. Baker 2005, 2009; Graham and Pettinato 2001; O’Rourke and Sinnott 2001; Mayda and Rodrik 2005; Seligson 1999; Scheve and Slaughter 2001). Because the economic importance of trade is growing worldwide, citizens can and often influence macroeconomic policymaking, and women comprise greater than 50\% of the population in most countries, women's distinct preferences in this major policy area are an important phenomenon to consider.

While earlier studies have posited multiple explanations for general attitudes toward trade policy, no well substantiated account of the gender component of trade attitudes has emerged. The few studies focusing specifically on the gender-trade attitudes nexus underscore exposure to economic ideas (Burgoon and Hiscox 2004) and consumption decisions (Hall, Kao and Nelson 1998), while those examining general attitudes toward trade have employed not only these two approaches (e.g. Baker 2009; Hainmuller and Hiscox 2006), but have also emphasized more traditional mobile factors (Scheve and Slaughter 2001) and specific factors (Mayda and Rodrik 2005) approaches, in addition to considering education as human capital (Gabel 1998) and sociotropic concerns (Mansfield and Mutz 2009).

While this research seeks to address all of the above approaches in order to explain gender differences in trade attitudes, it emphasizes the concept of labor mobility as the most useful theoretical starting point. We posit that it is not women in general who tend to be negative toward trade but particularly women in the less abundant labor factor - higher or lowerskilled depending on the country context - who have heightened concerns about open trade's 
negative effects on them. In particular, these individuals tend to be more concerned about the potentially disruptive economic effects that such policies might have on them or their families.

One of the central obstacles to testing theoretical propositions related to explaining trade policy attitudes has been the limitations of the available data. Most public opinion surveys ask respondents to provide only a general opinion about free trade and researchers are left to conjecture as to which particular aspect(s) of trade policy and/or its effects the respondent is reacting. ${ }^{1}$ Trade is complex and few surveys bother to ask questions about its meaningful components, a shortcoming that poses serious problems for direct testing of many key hypotheses. Trade, and more importantly, changes in trade policy, can have a number of major implications for individuals and societies, and respondents are likely to be more concerned about the particular aspects that most affect them or their household, including, for example, trade's effects on consumption, jobs (theirs and/or employment more broadly) and economic growth. These specific concerns are the components shaping the "general" attitudes on which most researchers focus. Specific to this inquiry, the existing literature suggests that there may be a gendered component to many of these aspects, including those related to economic security and consumption.

Ideally, in order to determine more effectively why women are generally less receptive to trade liberalization, survey questions need to ask directly about the specific aspects and/or effects

\footnotetext{
1 The following surveys include general questions about attitudes toward trade or trade policy: the American National Election Study or NES 1992 (Blonigen 2009; Scheve and Slaughter 2001); Globescan International Survey 2003 (Baker 2009); International Social Survey Program or ISSP 1995 (Mayda and Rodrik 2005; O’Rourke and Sinnott 2001); Knowledge Networks 2007 (Mansfield and Mutz 2009); Latinobarometro 1996 (Beaulieu, Yatawara and Wang 2005), 1997 (Baker 2009); the National Annenberg Election Study 2004 (Mansfield and Mutz 2009); Pew Global Attitudes Project 2002, 2007 (Baker 2009); Time-Sharing Experiments for the Social Sciences or TESS 2003 (Burgoon and Hiscox 2004); the Wall Street Journal Americas 1998 (Baker 2009); the World Values Survey 199092, 1995-97, 1999-2001 (Baker 2005, 2009; Kaltenthaler, Gelleny and Ceccoli 2004 use 1995-97 only). Baker (2009, Chapter 8) utilizes some questions from his 4-City Survey (Brazil - 2005) about particular aspects of trade but uses them to create an index and explore a different theoretical inquiry.
} 
of trade policy that might be affecting women differently. Such data are even better if they are collected across space and time. Researchers can then employ these more nuanced responses as dependent variables in order to test competing or complementary theoretical propositions more meaningfully. Exploring gender differences in individuals' wide-ranging concerns about trade's effects on different facets of economic security helps to ensure that the findings are robust. The breadth of question also can help to disentangle the effects of major causal and/or other important variables that are otherwise lumped together in the general questions.

Several recent major public opinion surveys across three disparate countries or sets of countries the U.S., six major Latin American countries and five countries with predominant or large Muslim populations - offer excellent opportunities to explore some of these complexities because they probe deeply and widely into individuals' perceptions of and attitudes toward trade and its effects. Survey themes include economic security concerns - e.g. jobs, overall economic growth, markets for exports, pocketbook economic concerns, etc - and consumption, while also collecting other crucial individual-level data such as educational attainment. A multi-country and region research design serves to identify any divergence in gender's effects on trade attitudes between developed and developing countries, thereby helping to test a mobile factors theory more effectively.

The empirical findings of this research suggest that a mobile factors approach is a useful theoretical starting point in an explanation of gender differences in trade attitudes across a wide sample of countries. In the U.S., less educated women are more likely to have negative attitudes toward international trade and many things that it affects including consumption, workers and business. On the other hand, women with higher levels of formal education in the U.S. are more likely to report that trade has positive effects on the country's workers and consumption. In 
contrast, in developing countries, it is educated women who are more likely to view aspects of trade more negatively, including its effects on jobs, markets and consumption in Latin America, and trade overall and domestic business in the Muslim-country survey, while less educated women in the Muslim-country survey view trade’s effects on domestic business positively. As we develop below, women who are more likely to feel economically less secure because they are part of the scarce factor are more skeptical toward freer trade and its many facets, which include women with less education in developed economies and with more education in many emerging economies. In many of these developing countries, educated women are relatively new to their more skilled jobs in the labor marketplace and in times of major economic change - such as changes caused and/or exacerbated by trade policy reform - they may feel more vulnerable to the disruptions that often occur.

The paper is organized as follows. Section II discusses the literature and develops the theoretical framework. Data and the methodology are given in Section III; while Section IV presents the empirical results. Alternative explanations are discussed in Section V. The paper ends with concluding remarks in Section VI.

\section{Literature and Theoretical Framework}

The existing literature on trade policy attitudes has established empirically that a number of theoretical approaches offer explanatory utility. Recognizing this utility and because there are no compelling reasons that these explanations need to be theoretically or empirically exclusive of each other, we employ a framework that seeks to integrate them. However, because the literature on trade attitudes has grown somewhat vast, we will focus in this section on the approaches that 
have been most directly associated with gender and/or are most germane to our broader argument, including economic security, consumption, education/knowledge and risk.

\section{II.a A Mobile Factors Approach and Economic Security}

A major component of economic security is personal labor mobility. In a mobile factors approach to explaining trade attitudes, individuals in the abundant labor factor - higher-skilled in developed countries and lower-skilled in developing countries - are more likely to prefer policies of freer trade because they are theoretically better positioned to thrive in a more liberalized economy. ${ }^{2}$ Researchers argue that the goods or services generated by the abundant labor factor are comparatively more competitive in the global marketplace, which garners those workers higher wages. The corollary suggests that individuals in the scarce factor - lower-skilled in developed countries and higher-skilled in developing countries - will be more wary of liberalized trade because their industry will not do as well thereby mitigating demand for their skills and driving down their wages. ${ }^{3}$

We suggest that the scarce-factor dynamic is particularly heightened for women because they potentially face even greater economic and workforce constraints than men and stand potentially to lose more from policies that may cause economic distortion or dislocation. Many researchers have noted and some have demonstrated empirically that women often bear a disproportionate economic burden after liberalization (e.g. SIPA 2001, Tickner 2001). Therefore, women in the scarce labor factor face a veritable double burden: both their gender and their skill set appear to limit their economic opportunities. It is reasonable therefore to expect

\footnotetext{
${ }^{2}$ In an analysis of the relationship between trade policy and inequality, Dutt and Mitra (2002) also employ a framework consistent with a mobile factors approach. Though gender and inequality are of course distinct concepts, the multi-purpose nature of the general framework illustrates its broad utility.

${ }^{3}$ For in-depth general discussions of these approaches, see Baker 2009; and Mansfield and Mutz 2009.
} 
that these women will tend to be more skeptical of economic policy changes that present greater potential danger to their more precarious economic status, including trade liberalization.

Accordingly, we should be able to observe clear evidence of predictable differences among more and less educated women in both developed and less developed economies. In developed economies, women with more formal education, by virtue of being the abundant labor factor, should enjoy greater labor market flexibility and opportunity and be more positive toward different facets of trade. Also, in developed economies such as the U.S., less educated women are generally more economically vulnerable and should demonstrate wide-ranging and deeper concerns about liberalizing trade. Kucera and Milberg (2000) demonstrate empirically that in the higher-skilled Organization of Economic Cooperation and Development (OECD) countries, trade with countries with abundant lower-skilled labor has had a disproportionate negative effect on lower-skilled female workers in these more developed economies.

In developing countries, higher-skilled skilled workers are not only the scarce labor factor, but higher-skilled women in particular in many circumstances are newer to and a minority in the workforce, and are frequently the first to feel negative effects as labor demands change. Empirically, the ILO (2010) finds precisely this negative dynamic across a wide range of developing countries and regions: educated women are consistently facing lower wages, losing their jobs and not finding work disproportionate to educated men. ${ }^{4}$ Thus, policies such as free trade that can generate significant economic change are more likely to be viewed with skepticism and even negativity by these women. Finally, theory also suggests that less educated women in developing countries will be more likely to endorse freer trade. Recent empirical studies demonstrate that in the post-liberalization environment, wage gains for women have accrued

\footnotetext{
${ }^{4}$ It is important to note that mobile factors approaches assume full employment, which in strict terms, limits the theory to anticipating only wage decreases.
} 
disproportionately to the lower-skilled (Kabeer 2000; Mathew 2006; Saavedra 2001). Therefore, it is reasonable to expect that they might look at trade more positively than their better educated compatriots. However, this expectation should also be tempered with the complex economic reality that while lower-skilled women might be doing better than before economic opening, many studies show that trade liberalization generates winners and losers as labor is reallocated according to factor endowments and some groups of low-skilled women have also fared poorly (see Artecona and Cunningham 2002). ${ }^{5}$

Another component of the mobile factors approach is individuals' direct economic pocketbook concerns (e.g. Kaltenthaler et al 2004; Seligson 1999), because these concerns are closely associated with wages and consumption, and thus economic security of the individual and their household. Though studies have found only occasional evidence that these concerns drive individual-level attitudes toward trade, women may feel these microeconomic pressures more acutely than men. In recent decades, women have been taking an increasingly direct household management role in both developed and developing countries and pocketbook concerns may now be more important to many women because of these significant role changes (see Varley 1996).

Changes in trade policy might affect individual-level consumption and thus their broader economic situation. Recent research (see especially Baker 2003, 2009) argues that perceptions of improved consumption opportunities as a result of more open trade help to drive more positive

\footnotetext{
${ }^{5}$ A competing theoretical view posits a specific factors approach wherein the individual's industry strongly influences trade policy preferences. In brief, individuals in export-oriented sectors are more likely to support open trade while those in import-competing sectors prefer more closed trade policies (see Mayda and Rodrik 2005). In a recent working paper, Beaulieu and Napier (2008) test a specific factors hypothesis and a related tradables versus non-tradables hypothesis, and find that neither sectoral differences in employment nor employment in a tradable versus a non-tradable sector helps to explain gender differences in attitudes toward trade. They do find that the gender gap is more pronounced in developed economies than in developing ones, but do not offer an explanation. They conclude in part that the lack of a clear explanation of the gender gap in attitudes may be due to immeasurable differences between the attributes of males and females.
} 
attitudes toward liberalized trade. It is reasonable to expect that women - generally highly active in household-level purchasing - will strongly consider policies that potentially affect consumption. A recent survey of 12,000 women in 21 countries estimates that women are responsible for nearly two-thirds of purchasing worldwide (BCG 2008). With an increasing number of women heading households, perhaps especially so in developing nations, this proportion of purchasing will likely continue to increase. ${ }^{6}$ Accordingly, it is reasonable to anticipate that women's perceptions of the effects of trade policy on consumption - including the price, quality and variety of consumer goods - may directly affect their policy attitudes.

Hall, Kao and Nelson (1998) examine the historical relationship between female political influence and trade policy utilizing a logic that suggests that women have more of a consumption-based perception of trade policy and are going to be more in favor of liberalized trade because tariffs increase prices. Comparing U.S. tariff levels before and after women's enfranchisement, they find a gender gap wherein policy became more open - at least in terms of tariff levels - after this systemic change in voter eligibility, though they note the large number of possible conflicting or complementary explanations. In essence, the researchers are suggesting that women are more likely to condition their votes on changes in prices, while men tend to emphasize wages. The research, however, does not explicitly consider the interaction of gender and education.

Women's central interest in consumption presents at least two related theoretical possibilities. First, because women across education and income groups are generally active in household purchasing, the perceived consumptive benefits from trade might cause all women to look more favorably on this aspect of open trade (or even tilt general attitudes of women more

\footnotetext{
${ }^{6}$ Varley (1996) argues that women-led households are in fact dramatically undercounted because the convention has been to count only single-female-parent with dependents as "woman-led."
} 
positively toward open and/or international trade). Or second, women with more limited means - indicated best by lower levels of education and/or income - will be particularly attracted to the notion of getting more for their money (e.g. Booth et al 1993). Thus, women with lower levels of education and/or income will be more supportive of open trade because of its positive effects on consumption. Since all three surveys query respondents directly about how they think trade and/or trade policy is affecting their consumption, it is possible to examine this relationship directly.

\section{II.b Sociotropic}

Somewhat outside of the mobile factors framework, some scholars suggest that perceptions of the macroeconomic or "sociotropic" environment, including overall economic growth and/or broader employment opportunities in the general economy, have an effect on attitudes toward trade. For example, Mansfield and Mutz (2009) find that in the U.S., regardless of gender, respondents' sociotropic concerns have a resounding impact on their attitudes toward trade: people who view the economy positively are more supportive of open trade. In developing countries, where there is ample evidence that trade can disproportionately affect vulnerable segments of the population under certain circumstances, it is reasonable to expect individuals to demonstrate concern about trade's macroeconomic effects. But the theoretical expectations are complex and not well developed. For example, it is challenging to disentangle individuals' perceptions of their pocketbook concerns from sociotropic ones because it is not clear that people can make these distinctions clearly. Is it reasonable to expect that an individual would support free trade if it is working well for the broader economy but not for them individually? Finally, there are no clear expectations for specific gender implications. 


\section{II.c Ideas and Education}

Scholars have also focused on exposure to ideas and information about the economic principles of trade, as well as on education more generally, in order to explain trade attitudes. Hiscox and Hainmueller (2006) argue that the actual ideas that people learn are important in terms of shaping their attitudes toward trade. They posit that the fairly consistent positive relationship between education and support for free trade in developed countries that scholars have found is more a function of educated people's exposure to specific economic ideas. Burgoon and Hiscox's (2004) version of this basic argument includes a gender twist by suggesting that the gap between men and women is mainly a difference in their exposure to economic ideas. The authors argue that men are more likely to be exposed to ideas that support freer trade such as comparative advantage - for example, by being more likely to take a college economics class - and therefore will be more likely to prefer policies that correspond to these ideas. They test their hypothesis using data from the U.S. and find that incorporating knowledge of trade issues (or suitable proxies) considerably closes the gender gap even after controlling for alternative explanations including those more focused on mobility and consumption.

The logic of the "ideas" hypothesis is extremely challenging to test because it is necessary to know the actual ideas to which individuals have been exposed. One crude possibility is that college-educated women have generally been exposed to more economic ideas than women without a college education because of the relative sophistication of the subject material compared to other educational experiences (e.g. high school or vocational institutions), and they will therefore be more positive toward trade. Some important shortcomings of this claim are discussed in greater detail below. 
The human capital explanation interprets the role of education differently than the "ideas" approach. Scholars (e.g. Gabel 1998) who privilege the importance of human capital argue that no matter the context, people with more education are better poised to be more mobile in the labor market and will be more supportive of general social welfare-maximizing policies such as liberalized trade. Thus, regardless of their status in terms of factor abundance and/or the economic ideas to which they have been exposed, more educated people - including women should be more supportive of liberalizing trade.

In the cases of both the ideas and human capital, a clear pattern should emerge across the data and corresponding analyses below. If either or both are helping to explain some of the variation - and we will not be able to discern which with these data - we should observe consistently that better educated women support open trade.

\section{II.d Risk Preferences}

A strand of the economics literature examining why men and women often make different economic decisions privileges the role of risk. In particular, studies cite the possible gender effects of emotions; overconfidence; and interpretations of risk as threat or a challenge (see Crosson and Gneezy 2009 for a review), and some have argued that women tend to be more emotional and less "overconfident" than men, and more likely to interpret risk as a threat. Because economic liberalization by nature entails some, if not significant, risk, this logic could be used as a theoretical starting point to understand preferences toward changes in trade policy.

While we cannot test these propositions directly - in fact, most of this literature is based on controlled laboratory experiments - we can predict the general results that we should observe if this logic is suitable to helping to explain trade preferences. If women by "nature" are simply 
more emotional, less overconfident and see risk as a threat, there should be systematic evidence of women, ceteris paribus, being more likely to reject the riskiness of a potentially changed economic context - i.e. liberalized trade - no matter their status in terms of factor endowments. To further complicate this proposition, however, some researchers (e.g. Atkinson et al 2003) have found that education and knowledge can attenuate gender differences in economic decisions. If this is the case then we should see clear evidence of educated and/or tradeknowledgeable women more likely to support trade liberalization.

\section{Data and Methodology}

\section{III.a Data}

The data are drawn from three recent public opinion surveys. The surveys were administered in the U.S., the six countries in Latin America with the largest economies (Argentina, Brazil, Chile, Colombia, Mexico and Venezuela); and five countries with predominant or large Muslim populations (Azerbaijan, Egypt, Indonesia, Nigeria, and Turkey). ${ }^{7}$ This collection of surveys provides considerable variation in terms of the average income, the type of political system and the structure of the national economies, among other country-level variables.

The U.S. survey is "Fortune Magazine Poll \# 2008-4311: Economy,” which was fielded in 2008 by Abt - Schulman, Ronca \& Bucuvalas, Incorporated (SRBI). The survey sought to examine the attitudes of 1000 randomly-selected individuals toward the U.S. economy and related issues in the first year of the worldwide economic crisis.

\footnotetext{
${ }^{7}$ The broader Muslim-country survey also included Great Britain, Iran, and Palestine, but questions about trade were excluded entirely for Great Britain and Iran, and basic demographic variables were excluded for Palestine. Where possible, we run alternative analyses in order to include Palestine, and consistently; these results are similar to those presented in this research.
} 
The survey from Latin America was executed in six countries in late 2005 by Zogby International and the University of Miami. The surveyors specifically targeted 500 people that the pollsters identified as "leaders" or "opinion-makers" - people with high-level government jobs, management positions in private industry, a salaried position in a media company (e.g. television, print, radio, etc) or holding some type of elected public office. In other words, all of the respondents were either well educated formally or at least informally through their work experience. While the lack of variation in educational level makes the data less ideal for the purposes of this inquiry, the range of questions that permit a variety of relevant dependent variables justifies the survey's inclusion. Moreover, though the bias in the data generates obvious limitations in terms of educational group comparisons, it makes the implicit tests for both the ideas and human capital hypotheses even stiffer. In other words, because most of these respondents demonstrate greater than average levels of both education and human capital, we should observe continuity in (the positive) responses if the education and/or human capital propositions are correct. Finally, the notion that elites wield considerable policy influence has been theoretically well developed (e.g. Zaller 1992) and tested empirically in many contexts, including Latin America (e.g. Baker 2009; Bishin, Lebo and Barr 2006).

The third survey was administered in countries with predominantly or large Muslim populations in early 2008 by www.worldpublicopinion.org, which is a collaborative project involving research centers from around the world and managed by the Program on International Policy Attitudes (PIPA) at the University of Maryland. The original survey sought the opinions of a random sample of more than 5,000 individuals in eight countries about globalization and related issues including international trade. Four of the five survey countries are among the top ten countries in the world with the largest Muslim populations (all but Azerbaijan). 
Note that we are not attempting to integrate the findings from the analyses of the three surveys. We fully recognize that they are not readily comparable in such a direct fashion because of the different contexts of survey implementation and the different questions. However, we argue that there is inherent value in looking at the broader pattern of findings to determine if the effects are broadly consistent with theoretical constructs.

\section{III.b Dependent variables}

As the survey data permit, we seek to use dependent variables that examine both trade policy attitudes generally and individuals' attitudes toward trade's major effects, including on jobs, mobility, economic pocketbook issues, macroeconomic performance and consumption. While the precise questions vary, there is sufficient continuity across the three surveys to generate a meaningful discussion comparing the results (see Data Appendix A for the wording of each question).

In the U.S. survey, the dependent variables are direct queries about attitudes on trade generally, and its effects on the respondent personally, workers, business and consumption. The respondents have three options: "worse” (coded as -1), "neutral” (0) or "better” (1).

In the Latin America survey, questions ask about general free trade and specifically about freer trade's effects on jobs, economic growth, demand for a country's goods, and demand for exports. The general question utilizes a four-point ascending scale, where "very bad" is set to 1 and "very good" is set to 4 . The menu of possible answers for the trade effects questions is a five-point, ascending scale (1-5): very negative, negative, neutral, positive and very positive.

The last dependent variable from the Latin America survey is based on three consumeroriented questions. The survey asks respondents three separate questions about the effects of trade on the price, quality and variety of goods - giving the respondent the choice of negative (- 
1), neutral (0) or positive (1). Using the three responses, we create a simple additive seven-point consumer scale variable index (range $=-3$ to 3 ). In separate specifications, we also use the threepoint scale for each component of consumption to determine if there is a gender effect on these specific parts of the broader consumer issue (See Appendix B).

The questions in the survey of Muslim countries tap into the same conceptual issues as the other two surveys, including trade generally and trade's effects on consumption, job security, job creation, standard of living and domestic business. There is one additional question about trade's effects on the environment that is difficult to place directly in this research's broader theoretical discussion but which we include as a robustness and stability check for the significance and direction of the coefficients of the variables included in the other analyses. The possible answers to all of these questions are dichotomous: "good" (1) or "bad" (0).

\section{III.c Independent Variables}

Considering the theoretical inquiry of this research, the first independent variable is gender. Following most research, it is a dummy variable where "female" is set to 1. Drawing from the general literature on trade attitudes, other key variables include: education; age; income; prospective economic outlook; and ideology and/or political party. Where data permit and there is compelling theoretical logic and/or strong precedent in the literature, we include several other controls in some analyses.

The second major independent variable most relevant to this theoretical inquiry, education, is a very complex variable in the trade attitudes literature and as discussed above is often poorly developed theoretically. Scholars use it to represent mobility by identifying if an individual is part of the abundant factor, the level of individual human capital, and "knowledge" about trade and related economic issues. 
In this research, it is particularly important theoretically to determine how more and less educated women react to trade liberalization, and if there are distinct patterns across different types of countries. Accordingly, in order to generate a meaningful interaction of education and gender in the U.S. and Muslim-country surveys, we first dichotomize education into college graduate and those who are not college graduates. Hainmueller and Hiscox (2006) present empirical data supporting the contention that college education - more than any other type of education - has a measurable and significant effect on support for free trade. We then create an interaction between the two dummy variables: college graduate and female. In addition, in contrast to using the ordered education variable in the interaction term, generating an interaction of gender and the dichotomous education variable permits more meaningful interpretations of the constituent terms. The female constituent term represents women who are not college graduates, while the college graduate constituent term represents males with college degrees. In the Latin America dataset, the sample is comprised of elites so there is little variation on the education variable as most respondents have a college education while many more hold additional graduate or professional degrees. We do not create an interaction variable initially but do include an education variable in order to examine the effects of higher education more generally as the data permit. In the Latin America survey, education is a six-point scale where 1 represents no high school, 2 is some high school, 3 is a high school graduate, 4 is some college, 5 is college graduate, and 6 is a graduate or professional degree.

Age is generally linked by scholars to mobility. People who are older are thought to be less able or perhaps less willing to relocate, so policies such as liberalizing trade that can have implications for dislocating workers are often less popular with them. In each dataset, age is a continuous measure by year. 
Like education, income is also often poorly developed theoretically. High incomes can indicate some level of mobility. High incomes can also indicate more consumptive power. Income is also usually highly correlated (and/or causally related) to education, so it is not easy to disentangle these complexities. In any event, it is positively related to attitudes toward open trade and statistically significant in most research. In terms of measurement across the surveys, though the actual increments are different, the measures are conceptually similar. The U.S. survey uses a seven-point scale: 1 represents respondents reporting income less than $\$ 20,000$; $2=\$ 20,000$ to just under $\$ 35,000 ; 3=\$ 35,000$ to just under $\$ 50,000 ; 4=\$ 50,000$ to just under $\$ 75,000 ; 5=\$ 75,000$ to just under $\$ 100,000 ; 6=\$ 100,000$ to just under $\$ 150,000$; and $7=\$ 150,000$ or more. In the Latin American survey, income is a five-point scale where 1 is respondents reporting annual income less than $\$ 15,000$ (USD); a 2 represents $\$ 15-30,000$; $3=\$ 30-45,000$; $4=\$ 45-60,000$; and $5=$ greater than $\$ 60,000$. In the Muslim-country survey, using specific scales for each country relative to cost of living, the surveyors use a three-point income scale of low, medium and high, which we code from 1 to 3 respectively.

Studies have found a consistent positive relationship between broader macroeconomic outlook and attitudes toward open trade (see particularly Mansfield and Mutz 2009). Though theoretically it is challenging to disentangle this notion from mobility and/or economic security distinctly (and from several of the dependent variables, too), it appears likely that many citizens consider the broader economy and link those perceptions to the policies that may be affecting it, including trade policy. In the U.S. and Latin America surveys, there are questions about prospective economic outlook. In the U.S. survey, the question is a short-term prospective one where the survey asks if the economy is "getting better" (coded 1 ), staying the same (0), or getting worse (-1).” In the Latin America survey, the question asks: Within the next two years, 
do you expect the economy in your country to... decline greatly (coded as 1), decline somewhat (2), improve somewhat (3), or improve greatly (4). There are no sociotropic questions asked in the Muslim-country data, nor any questions that could serve as a reasonable proxy.

Though it has been much less consistently demonstrated in the empirical research, some scholars posit that attitudes toward trade policy are shaped by more of a personal economic interest or "pocketbook" concerns (e.g. Kaltenthaler et al 2004). Only the U.S. survey asks a pocketbook economic question: Just thinking about your own personal economic situation, do you feel that over the past twelve months things have gotten better (coded as 1), worse (-1), or stayed about the same (0)?

Some researchers have posited a strong link between ideology and attitudes toward trade. But once again, the theoretical logic is far from clear. On one hand, from the viewpoint of a mobile factors approach, political parties that are supported largely by the abundant labor factor should have supporters that are in favor of more open trade. In developed countries, these parties should be right-leaning and supported by capital and higher-skilled citizens, and in developing countries, these parties should be left-leaning and supported by lower-skilled labor. While this dynamic seems to hold well in developed countries, scholars have found more support for openness in some developing countries from right-leaning parties (e.g. Magaloni and Romero 2008) or a near convergence in support for more open policies between the left and right (e.g. Armijo and Faucher 2002; Kingstone and Young 2009). The U.S. and Latin America surveys offer data on political party affiliation and ideology. For the U.S. data, we code the political party variable on a five-point scale with strong Democrat coded to 1, a leans-Democrat coded as 2, an independent that reports no leaning to either party as 3, a leans-Republican as 4 and a 
strong Republican coded as $5^{8}$ In the Latin America data, we use a simple dichotomous measure if the respondent indicates that they self-identify as supporting a left-leaning political party.

In Latin America particularly, some research has emphasized the strong support from the business sector for policies of trade openness in the post-reform era (e.g. Armijo and Faucher 2002). Considering that business tends to lean right ideologically, this hypothesis is in some tension with a narrow interpretation of the mobile-factors approach and its predictions for how the less abundant factor should be negatively-oriented toward open trade. To include this dynamic in the analysis of the Latin America survey, we generate a dummy variable for those respondents who self-identify as working in the business sector.

In order to examine preliminarily the trade knowledge hypothesis (see Burgoon and Hiscox 2004) using the U.S. survey data, we include a measure of self-identified trade knowledge. Of course, whether the respondent is qualified to assess their own actual knowledge of trade is a separate but important issue; in effect, in many cases, it is more likely a measure of issue salience than actual knowledge. In either event, we argue that it is a useful control. The question asks: On another topic, compared to most other issues in the news, how closely do you follow news about United States trade with foreign countries very closely (3), somewhat closely (2), not very closely (1), or not at all (0)?

\section{III.d Methodology}

The nature of the ordered responses in the U.S. (three-point) and Latin American datasets (four- and five-point) suggests the use of ordered probit. For the Muslim country dataset,

\footnotetext{
${ }^{8}$ A separate question in the survey asks respondents if they self-identify as liberals or conservatives. We use this measure as an alternative, and it produces substantively similar results to the political party variable.
} 
because the questions ask only if the respondents think that trade is good or bad in relation to specific issues, we code the answers dichotomously ( 1 and 0 respectively) and utilize an appropriate multivariate method for binary outcomes, probit analysis. ${ }^{9}$ As a general check on the robustness of the results from the analyses using ordered dependent variables, we try dichotomizing these ordered dependent variables so that " 1 " indicates any positive response, and re-run the analyses using regular probit analysis. The results do not change substantively from the ordered probit analyses using the more nuanced responses (presented in the tables). ${ }^{10}$

Because country-level traits might affect the results, we include country dummies. It is likely that specific characteristics of certain countries affect the results, but without more countries to establish a sample at this higher level of analysis, it is not possible to control meaningfully for these possibilities. In an ideal scenario, a hierarchical model would be utilized (see Baker 2005, 2009), but under the constraints of the data - particularly too few countries in each survey - the best alternative is the use of a set of country dummies. For the Latin America surveys, we use Mexico as the baseline country because we expect that its exceptionally close trading relationship with the U.S. makes it distinct from its Latin American neighbors. For the Muslim-country survey, we use Nigeria as the baseline because of its huge petroleum-based economy, unique among the five countries. For the sake of simplicity of presentation and because the country variables are not directly germane to the theoretical discussion, we do not include them in the results in the tables.

\footnotetext{
${ }^{9}$ We run the ordered-dependent variable models for the U.S. and Latin America using ordered logistic regression and these models produce substantively similar results to the ordered probit models in terms of direction, size and strength of the coefficients. Similarly, we run the analyses for the Muslim-country data using logistic regression and the results are almost identical.

${ }^{10}$ We also run these analyses using logistic regression and the results are substantively similar.
} 


\section{Results and discussion}

The results from the empirical analyses of the three different surveys reveal convincing preliminary evidence supporting a mobile factors/economic security-focused theoretical argument to explain gender differences in the perceptions of trade policy, as well as an inherent complexity to trade attitudes. Consistent with the predictions of this research's theoretical framework and Beaulieu and Napier's (2008) finding, the results demonstrate that there are marked differences in how gender affects attitudes toward trade among those respondents from the developed country and the developing countries in these analyses. In brief, in the U.S., the interaction between gender and education demonstrates a mostly positive effect on trade attitudes: college-educated women tend to see the effects of international trade more positively. The even stronger corollary suggests that women without a college education tend to be more negative toward open trade in general and many of its effects. In contrast, in developing countries, the results of the multivariate analyses suggest that educated women tend to be more negative toward freer trade or international trade more generally and many of its effects.

Overall, these results for gender undoubtedly have affirming implications for the utility of a mobile factors hypothesis. Note particularly that women in the abundant factor in the developed country - i.e. those who are higher-skilled - are more supportive of free trade, while educated women in the developing countries, who comprise part of the scarce labor factor, are more negative about open or international trade. These findings essentially support what a mobile-factors-based theory would predict. Moreover, the totality of the evidence - negative attitudes toward multiple, wide-ranging aspects of international trade and its effects - suggests that the findings are pretty robust. The results for both the developed and developing countries 
are robust across a number of dependent variables representing general trade and its various major effects, which suggests that women are conceptualizing multiple aspects of trade policies and corresponding effects relatively consistently.

On a related note, a mobile factors approach assumes full employment. While it is reasonable to argue that women are concerned about wage levels, it is likely that they also have grave direct concerns about their employment status - i.e. job or no job - and concerns well beyond the individual level. The results from these analyses clearly bear out women's broad concerns about trade liberalization. These more comprehensive interpretations, however, are not well accounted for theoretically in a strict mobile factors approach, so it seems reasonable to consider relaxing this assumption to allow for these concerns.

\section{IV.a U.S. Survey}

The results from the U.S. survey (Table 1) point to a marked divergence between collegeeducated and less educated women. Moreover, these results are robust across most of the different dependent variables - the particular focus of the question about trade and/or its effects simply does not seem to matter much. These findings also suggest strongly that the consistent negative general finding for gender may be driven in considerable part by women with less education in developed countries. The results demonstrate that the coefficients of the constituent female variable - which represents women without a college education - is negative and significant not only in the analyses utilizing the consumer and workers dependent variables, but also the macro-economy and business dependent variables. Women without college degrees are more likely to have a negative attitude toward most of the major components and/or effects of international trade. In contrast, the coefficients of the interaction between college-educated and 
female are positive and significant in the analyses with the consumer and effects on workers dependent variables. College-educated women are more likely to report that international trade is good for consumption and U.S. workers.

\section{IV.b Latin America Survey}

In the Latin America analyses (Table 2), the results are in significant contrast to the U.S. analyses, suggesting that female respondents, all of whom have been identified by the surveyors as "elites," are less likely to believe that more open trade is good for jobs, consumer benefits and new markets for their country's goods. ${ }^{11}$ In these three analyses, the coefficients of the female variable are negative and statistically significant at the $5 \%$ level. Elite women are more likely to believe that trade is not good for creating jobs, which speaks to concerns about their economic security. The results suggest that elite female respondents are also less likely to believe that policies of open trade improve consumer conditions. Where Baker (2003 and 2009) hypothesizes that people's perceptions of the relationship between trade and consumption are mainly positive, and Hall et al (1998) suggest that women in particular hold this viewpoint, this finding suggests that we should examine the relationship a little more closely from a gender perspective (and given the appropriate data - particularly wider variation on the education variable - perhaps, a gender and education interactive perspective). It is possible that women and men have different expectations for trade's positive or negative effects on consumption. In the three analyses that examine several macroeconomic components of trade, the results are somewhat mixed. In the analysis that examines the effects of more open trade on markets for a country's goods, the coefficient of the female variable is negative and significant at the five-

\footnotetext{
${ }^{11}$ As stated above, there is little variation on education (more than $90 \%$ of respondents are college-educated) so an interaction between education and gender in the Latin America analysis is not comparable to the other surveys.
} 
percent level. In the effects of freer trade on economic growth analysis, the gender coefficient is positive, and in the demand for exports analysis, the coefficient is negative, but neither coefficient is statistically significant. Finally, in contrast to much of the more general literature on attitudes toward open trade, in the analysis that examines general attitudes toward free trade, the gender coefficient is actually positive, though not statistically significant.

\section{IV.c Muslim-country Survey}

In the analyses using the Muslim-country survey data (Table 3), two of the results suggest a finding similar to the Latin American analyses that more educated women are less supportive of open trade, though the results are weaker - significant only at the less demanding $10 \%$ level. The negative finding is for both the general trade question and the question about international trade's effects on the respondent's country's domestic businesses. Notably, the results also suggest that less educated women believe that open trade is good for domestic business. ${ }^{12}$ The implication of this finding is not entirely clear but may have to do with the nature of business in which less educated women are more likely to participate in these countries: service industries. If for example, women help to run small retail businesses, it is possible that the prospect of more and cheaper imported goods to sell is attractive. Finally, in the other five analyses that examine effects of international trade on consumption, job creation, job security, standard of living and environment, neither gender nor the interaction between gender and education is significant. This important finding of little or no effect across most of these

\footnotetext{
${ }^{12}$ In an otherwise identical analysis but without the interaction of female and education, the coefficient for gender is positive and significant only in the domestic business analysis. It is important to note that the inclusion of the interaction of the college graduate and female variables suggests strongly that less educated and more educated women diverge in their perception of trade's effect on domestic business. Such results raise the possibility that gender variables that are not statistically significant in analyses of individual attitudes toward trade policy may be instances where two or more groups of women with differing viewpoints are dulling the overall gender effects precisely because meaningful interactions are not adequately incorporated.
} 
analyses suggests that there is a less strong gendered component to trade attitudes in these five developing countries with large or predominant Muslim populations. It is possible that women are less engaged economically in societies that tend to privilege the roles of males, but more research is necessary to explain meaningfully why there are more limited effects of gender, especially compared to Latin America and the U.S.

\section{IV.d Consumption}

The consumption findings suggest a notable contrast between the U.S. and Latin America. The results from the U.S. survey strongly indicate that educated women in the U.S. are far more likely to believe that international trade has positive effects on consumption, while less educated women are much more likely to be negative. The first finding may be consistent with Hall et al's (1998) theoretical supposition about perceptions of the link between tariffs and price. But, in terms of their attitudes toward trade, at the time of this survey (2008), concerns about jobs appear to trump the benefits to consumption for U.S. women with lower levels of education, which is quite a reasonable finding in light of the scope and magnitude of the worldwide economic crisis. It is clearly difficult to parse out if individuals are more focused on changes in price or wages stemming from globalization,

The finding that female elites in Latin America do not generally have a positive outlook toward trade's effects on consumption runs counter to the U.S. finding and is an interesting addendum to some previous research. Baker $(2003,2009)$ finds in a number of rigorous models using multiple public opinion surveys that people in Latin America are generally supportive of free trade in some part because of its benefits for consumption. The findings in this research suggest that previous positive results may be driven largely by certain discrete groups - e.g. men and/or less-educated women. More research needs to be done in order to identify and explain 
better patterns of attitudes across different types of groups of respondents, and to examine more rigorously what individuals believe is positive or negative about how open trade affects their consumption. Building on the latter goal, we seek to disentangle preliminarily the components of consumption by running separate analyses for the three components that comprise the sevenpoint consumption index used as the principal dependent variable: price, quality and variety of goods. We find statistically significant gender differences on trade's effects on price and quality (both negative), but not on the variety of goods (see Appendix B). ${ }^{13}$

\section{IV.e Education and/or Knowledge}

The divergent results between the U.S. and the emerging or developing countries in these surveys suggest that scholars need to pay closer attention to issues of education and knowledge. While this research finds generally what many other scholars find in terms of educated people in the U.S., and perhaps especially educated women, having more positive viewpoints toward open trade (e.g. Burgoon and Hiscox 2004; Hainmueller and Hiscox 2006), the preliminary finding of skepticism toward freer trade of more educated women in low- and middle-income countries is enormously important. While we argue for an economic security-focused explanation, it is possible that the hypothesis that the curriculum of the countries' universities deeply shapes people's opinion toward economic policy is also correct: in developed countries, higher education is perhaps more likely to extol the virtues of open trade, at least more than institutions of higher education in other countries. An alternative explanation is that educated women in developing societies recognize better some of the fundamental - often economic security-related

\footnotetext{
13 The logic of a consumption-based approach might suggest that lower and higher income women will have differing views on the effects of trade on their consumption power. Because basic goods comprise a larger proportion of income for someone that makes less money, it is reasonable to expect that lower income women will have statistically significant positive views of trade's effects on consumption. Accordingly, in separate specifications, I include a multiplicative term of the income and gender variables. The coefficients of the interactive term are negative but not statistically significant in the consumption analyses across the three surveys, a finding that is consistent across all of the analyses using other dependent variables, also.
} 
- challenges faced by individuals and specific groups as states liberalize their economies because these changes are more proximate to them. It is worth examining this possibility more as appropriate data - for example, university curricula in an appropriate broad sample of countries are generated by researchers, an enormous task well beyond the purview of this study.

This research does examine very preliminarily the closely-related issue of trade knowledge using the U.S. survey. The coefficients of the trade knowledge variable are mixed in direction and are never statistically significant across the five analyses. ${ }^{14}$ When we generate an interaction of trade knowledge and gender, it does not produce results that are statistically significant. Women who follow trade closely do not have views statistically different from women who do not follow the topic closely. It is possible that respondents do not really understand trade, and the survey question that this research utilizes is an unreliable measure. However, it is also possible that an individual's actual knowledge of trade does not affect their views of it in any discernible pattern - in other words, the distribution of those who are negative or positive toward trade openness is comparable no matter the level of knowledge, which is similar to the issues discussed directly above. Future surveys need to develop better questions that actually test people’s economic and trade knowledge more objectively.

It is also possible that particularly high levels of education have a different or heightened effect on trade attitudes. Gleason and van Scyoc (1995) have found that even after controlling for economics classes, those with graduate and professional degrees are markedly better informed about and better prepared to contemplate complex economic issues such as open trade. It is therefore reasonable to hypothesize that those with a graduate or professional degree are more "educated" about the ideas of freer trade (and perhaps have more mobility and/or human capital generally), and will therefore be even more supportive of freer trade policies than their

\footnotetext{
${ }^{14}$ Removing the knowledge variable from the analysis does not change any other result substantively.
} 
four-year degree counterparts. Also, Green et al (2001) argue that in Latin America, workers with intermediate skills have been particularly hard hit by trade liberalization while those with the highest skill levels have done comparatively well. We utilize the Latin America survey to examine these arguments and do not find that respondents (men or women) with graduate or professional degrees have different views than those with some college or a bachelor's degree. More generally, the results of the education variable (not interacted with gender) in the Latin America survey seem to buttress the contention that "knowledge" or "education" could cut either way. The coefficients for education are significant at the $5 \%$ level in two of the six analyses, but notably, the direction of the coefficient changes between the two analyses. In the growth analysis, education is negative and significant suggesting that the most formally educated respondents are actually more likely to think that freer trade is not good for overall economic growth. However, in the consumer analysis, the coefficient is positive and significant suggesting that the most educated respondents are more likely to report that trade is good for consumer issues. The coefficient for education is also positive in the jobs analysis, though statistically significant at the less demanding $10 \%$ level.

\section{IV.f Risk}

As acknowledged above, we cannot effectively test risk-based hypotheses directly with these data, but the general trends suggest that risk might be a situation-specific explanation. If women are more risk-averse naturally then we should observe systematic negative trends in women's attitudes toward trade across these surveys. These results do not bear out such a consistency. Furthermore, if knowledge attenuates risk, it remains a puzzle why educated women in developing countries are more risk-averse than their less-educated counterparts. Considering the complexity of the relationship between risk and trade attitudes, a next logical 
step in terms of testing these potential explanations might include more work out of the experimental laboratory.

\section{Alternative Explanations}

While the results for many of the control variables vary among the analyses depending on the survey and the particular dependent variable, there are some consistent findings of theoretical note. One of the most stable findings using the U.S. and Latin America surveys is the direction and significance of the coefficients for prospective economic outlook variable: in nearly every analysis, the coefficients of this variable are positive and statistically significant. This finding is consistent with Mansfield and Mutz's (2009) finding across two national surveys in the U.S. If a respondent is optimistic about the nation's economic prospects, they are much likelier to support trade generally, or to think that it has positive effects on specific facets of the economy (e.g. consumption, mobility, macroeconomic, etc.).

There are, however, potential problematic issues with sociotropic variables that scholars sometimes do not acknowledge sufficiently. Undoubtedly, there is genuine potential for tautology because the crude logic suggests that (dis)satisfaction with the economy leads to (dis)satisfaction with a major component of the economy - i.e. trade. On a closely related note, it is difficult to know whether sociotropic issues belong on the left- or the right-hand side of the empirical equations. There is a reasonable case for both and scholars have to consider these issues carefully.

In the Muslim-country survey, the coefficients of the Muslim dummy variable are negative and statistically significant in seven of the eight analyses (not the consumer dependent variable), suggesting that Muslim respondents are much less likely to support trade generally or 
to think that it has positive impacts on any major aspect such as jobs or the macro-economy. There could be myriad explanations for this finding and it deserves considerably more investigation in future research, particularly considering the general conclusion of the surveyors that Muslims are generally supportive of globalization, which was based on aggregated responses not on multivariate analysis with appropriate controls (World Public Opinion 2008).

Age demonstrates an unanticipated divergence between the U.S. and the two developing country surveys in terms of the direction and consistency of the statistical significances of the coefficients. As with many other empirical studies, the findings for age in the U.S. survey suggest a negative relationship: older people are less likely to be supportive of free trade or to believe that it has widespread positive effects. In all analyses for the U.S., the coefficients for age are negative, and in four of the five analyses, they are statistically significant. Age is statistically significant in only two of the six Latin American analyses, but in contrast to the U.S. analyses, in both the demand for goods and jobs analyses, the coefficients are positive and statistically significant. Apparently, older people in Latin America are more likely to believe that trade is good for the demand for a country's goods and for the availability of jobs. Similarly, in the Muslim-country survey, age is positive in all analyses, though only significant with the job security and environment dependent variables. It is possible that in many developing countries, older people recall the long-term economic challenges associated with closed economies, though new survey data would be necessary to address this issue effectively.

As discussed above, across the analyses, income is fairly consistently positive and significant at the 5\% level in nearly half the analyses. Respondents with higher incomes are more likely to deem trade as good generally, or positive for specific aspects of their lives or for their country. 
Ideology and political party are not strong predictors of attitudes toward trade policies. In the U.S. results, the coefficients of the political party variables are never statistically significant and are inconsistent in terms of direction. Similarly, with the Latin America survey, the signs flip in the two analyses where the coefficients of the ideology measure are significant: the coefficient in the general trade analysis is negative while it is positive in the analysis utilizing the jobs dependent variable. Perhaps oddly, respondents who self-identify as left-leaning are less likely to be positive toward policies of freer trade, while being more likely to believe that freer trade is good for jobs. But this inconsistency may be partly explained by wide changes in the workforces in many emerging economies, while also fitting into the theoretical model employed in this research. In many developing countries experiencing more robust growth, the labor market is no longer obviously bifurcated between low- and high-skilled workers. In fact, many countries, such as Brazil and Mexico, have an increasingly higher skilled workforce. These changes certainly make the application of a simple mobile-factors model more problematic. More importantly to the theoretical inquiry of this research, these changes in workforce composition also appear to be generating more uncertainty - at least temporarily - for particular groups, including educated women.

In the Latin America results, the coefficients for the business dummy are positive and significant only in the analyses using the general free trade and consumer dependent variables. Those who self-identify as working in business are more likely to be positive toward free trade and to believe that freer trade is good for consumption-based issues. Though scholars suggest an iron-clad link, support for free trade from those in the business sector is not universal across all aspects/effects of trade. Again, an explanation for the inconsistency may lie in the economic changes in many of these countries. "Business" is far from a monolithic group: the re-structuring 
of many sectors as a result of more open trade creates both winners and losers, and the tension between these groups in regard to attitudes toward trade may be reflected in the lack of statistical significance.

\section{Conclusions}

By using an original analytical approach that focuses not just on general attitudes toward free or international trade, but for the first time on a significant scale, on attitudes toward the issues and components of free/international trade and its effects, this research generates some valuable theoretical insight into and empirical illustrations of how gender may be affecting preferences toward trade policies. The evidence suggests that a mobile factors/economic security approach helps us to understand better how gender is affecting trade policy attitudes. Women who perceive that they are more economically secure or perhaps observe better economic prospects - at least in the face of trade policy change - tend to be more sanguine about trade liberalization, including college-educated women in the U.S., and to some extent, less educated women in developing countries. In contrast, women who find themselves in more vulnerable economic positions - less educated women in the U.S. and better educated women in developing countries - are more skeptical about policies of freer trade. Considering that the

preponderance of research on trade attitudes includes only developed countries and finds a consistently negative gender effect, this very robust finding for the U.S. is enormously important. Moreover, these findings are robust to trade’s broader economic effects - similar patterns clearly emerge across multiple facets of trade. While scholars must do more work to test these relationships, empirical evidence supporting broader mobile factors of trade attitudes explanations may be partly driven by gender. 
The findings that educated women in developing nations are not generally positive about trade clearly challenges the central notion of the human capital argument - more education does not necessarily automatically translate into support for economic liberalization. Scholars need to dissect the possible components of education better. In particular, in most research, the mobility, human capital, knowledge and ideas components of education are not sufficiently distinct. For mobility and human capital, it would be helpful to have a better idea of just how mobile an individual is beyond their general level of education. To examine better the knowledge and ideas arguments, scholars need to probe the individual's technical background and preconceptions about principles of trade more objectively, not only by testing their economic and trade knowledge, but also by determining better what is being taught in universities or other educational venues concerning trade, and how the media are presenting these issues in each country.

The theoretical implications of these findings demand further testing of the economic security-focused propositions in new and different contexts. This research generates compelling results from analyses using public opinion data from the U.S., six large Latin American countries, and five important predominantly Muslim countries in Asia and Africa that offer some insight into why women have different trade policy preferences than men, but the more we can test these propositions across time and space, the more likely that we will be able to identify these relationships more unambiguously. Hopefully, too, more pollsters will ask about attitudes toward trade's effects on multiple relevant aspects and not the blunt, much less useful, instrument that has been ubiquitous in previous surveys. Similarly, surveys executed with similar methodologies across multiple, varied countries over time would greatly enhance our abilities to infer from these type of data. 
With trade policy continuing to be high on both national and international agendas, it behooves researchers and policymakers to learn more about how attitudes and preferences develop. A recent major event in Latin America demonstrates the importance of developing a better understanding of individual-level trade attitudes. The 2007 referendum in Costa Rica on the ratification of a free trade agreement among the Central American countries, the U.S. and the Dominican Republic only narrowly passed and public opinion polls suggest that men were slightly more likely to support the pact than women. ${ }^{15}$ With such a close vote, for either the "yes" or the "no" side, the preferences of major discrete groups - such as women - were surely very important. Across time and space, there continues to be strong evidence of a gender component to differences in these individual-level trade policy preferences and this research takes important steps toward parsing out some of the explanations of this phenomenon.

\footnotetext{
${ }^{15}$ Surveys from both the Universidad de Costa Rica's (UCR) Escuela de Estadistica and Centro de Estudios de Opinion immediately after the referendum and Latin American Public Opinion Project in early 2008 suggest this result.
} 


\section{References}

Armijo, Leslie and Philippe Faucher. 2002. ““We Have a Consensus”: Explaining Political Support for Market Reforms in Latin America.” Latin American Politics and Society 44, 2: 1-40.

Artecona, Raquel and Wendy Cunningham. 2002. "Effects of Trade Liberalization on the Gender Wage Gap in Mexico.” Working paper - World Bank Development Research Group/Poverty Reduction and Economic Management Network.

Atkinson, Stanley M., Samantha Boyce Baird, and Melissa B. Frye. 2003. "Do Female Mutual Fund Managers Manage Differently?” Journal of Financial Research, 26, 1: 1-18.

Baker, Andy. 2003. "Why is Trade Reform So Popular in Latin America? A Consumption-Based Theory of Trade Policy Preferences.” World Politics 55, 3: (April):423-55.

Baker, Andy. 2005. "Who Wants to Globalize? Consumer Tastes and Labor Markets in a Theory of Trade Policy Beliefs.” American Journal of Political Science 49, 4: 924-38.

Baker, Andy. 2009. The Market and the Masses in Latin America. New York: Cambridge University Press.

Beaulieu, Eugene and Michael Napier. 2008. "Why are women more protectionist than men?," Working Paper, Department of Economics, University of Calgary.

Beaulieu, Eugene, A. Yatawara and W.G. Wang. 2005. "Who Supports Free Trade in Latin America.” World Economy 28, 7: 941-59.

Bishin, Benjamin G., Robert R. Barr and Matthew J. Lebo. 2006. "The Impact of Economic Versus Institutional Factors in Elite Evaluations of Presidential Progress Toward Democracy in Latin America.” Comparative Political Studies 39, 10: 1194 2019.

Blonigen, Bruce A. 2009. "New Evidence on the Formation of Individuals' Trade Policy Preferences.” University of Oregon and NBER Working Paper.

Booth, David, F. Lugngira, P. Masanja; A. Mvungi; R. Mwaipopo; J. Mwami and A. Redmayne. 1993. Social, Economic and Cultural Change in Contemporary Tanzania: A People Oriented Focus. Stockholm: Swedish International Development Authority.

Boston Consulting Group. 2008. Global Inquiry into Women and Consumerism.

Burgoon, Brian A. and Michael J. Hiscox. 2004. "Why Do Men and Women Have Different Views about Openness to the World Economy?” Working paper. 
Crosson, Rachel and Uri Gneezy. 2009. “Gender Differences in Preferences” Journal of Economic Literature 47, 2: 1-27.

Dutt, Pushan and Devanish Mitra. 2002. "Endogenous trade policy through majority voting: an empirical investigation.” Journal of International Economics 58: 107-33.

Gabel, Matthew. 1998. Interests and Integration: Market Liberalization, Public Opinion, and the European Union. Ann Arbor: University of Michigan Press.

Gleason, Joyce and Lee van Scyoc. 1995. "A Report on the Economic Literacy of Adults.” Journal of Economic Education 26, 3: 203-10.

Graham, Carol and Stefano Pettinato. 2001. "Happiness, Markets and Democracy: Latin America in Comparative Perspective.” Journal of Happiness Studies 2, 3: 237-68

Green, Francis, Andy Dickerson and Jorge Saba Arbache. 2001. "A Picture of Wage Inequality and the Allocation of Labor Through a Period of Trade Liberalization: The Case of Brazil." World Development 29, 11: 1923-39.

Hainmueller, Jens and Michael Hiscox. 2006. "Learning to Love Globalization: Education and Individual Attitudes Toward International Trade.” International Organization 60 (Spring): 469-98.

Hall, H.K., C. Kao and D. Nelson. 1998. "Women and Tariffs: Testing the Gender Gap Hypothesis in a Downs-Mayer Political-Economy Model.” Economic Inquiry 36, 2: 320-32.

International Labor Organization. 2010. Global Trends of Youth Employment. Geneva: United Nations - ILO.

Kabeer, Naila. 2000. The Power to Choose: Bangladeshi Women and Labour Market Decisions in London and Dhaka. New York: Verso.

Kaltenthaler, Karl, Ronald Gelleny and Stephen Ceccoli. 2004. "Explaining Citizen Support for Trade Liberalization” International Studies Quarterly 48, 4: 829-51.

Kingstone, Peter and Joseph Young. 2009. "Partisanship and Policy Choice: What's Left for the Left in Latin America.” Political Research Quarterly 62, 1: 29-41.

Kucera, David and William Milberg. 2000. "Gender Segregation and Gender Bias in Manufacturing Trade Expansion: Revisiting the 'Wood Asymmetry'.” World Development 28, 7: 1191-1210.

Magaloni, Beatriz and Vidal Romero. 2008. "Partisan Cleavages, State Retrenchment, and Free Trade.” Latin American Research Review 43, 2: 107-35.

Mansfield, Edward and Diana Mutz. 2009. "Support for Free Trade: Self-Interest, Sociotropic 
Politics, and Out-Group Anxiety” International Organization 63, 3: 425-57.

Mathew, E.T. 2006. Emerging Tendencies in the Post-Reform Period. Thousand Oaks: Sage.

Mayda, Anna Maria and Dani Rodrik. 2005. "Why are some people (and countries) more protectionist than others?” European Economic Review 49: 1393-1430.

O’Rourke, Kevin and Richard Sinnott. 2001. “The Determinants of Individual Trade Policy Preferences: International Survey Evidence.” Brookings Trade Forum 2001. 157206.

Saavedra, Luz. 2001. "Female Wage Inequality in Latin American Labor Markets.” World Bank Policy Research Working Paper No. 2741.

Scheve, Kenneth and Matthew Slaughter. 2001. "What determines individual trade policy preferences?” Journal of International Economics 54, 2: 267-92.

School of International and Public Affairs. 2001. Learning from UNIFEM's Work on Gender and Trade: A Multi-Regional Assessment. New York: Columbia University - SIPA.

Seligson, Mitchell. 1999. "Popular Support for Regional Economic Integration in Latin America.” Journal of Latin American Studies 31, 1: 129-150.

Tickner, J. Ann. 2001. Gendering World Politics. New York: Columbia University Press.

Varley, Ann. 1996. “Women heading households: Some more equal than others?” World Development 24, 3: 505-520.

World Public Opinion. 2008. “Poll: Muslims Positive About Globalization, Trade.” Press release, August 27. Available at www.worldpublicopinion.org. Last accessed: July 8, 2010.

Zaller, John. 1992. The Nature and Origins of Mass Opinion. Cambridge: Cambridge University Press. 
Table 1 - Individual Attitudes Toward International Trade and Its Effects in the United States, 2008: Ordered Probit

\begin{tabular}{|l|c|c|c|c|c|}
\hline & General & Consumer & Workers & Business & Personal \\
\hline Female & $-0.27^{*}$ & $-0.37^{* *}$ & $-0.40^{* *}$ & $-0.37^{* *}$ & -0.22 \\
& $(0.13)$ & $(0.12)$ & $(0.15)$ & $(0.12)$ & $(0.12)$ \\
\hline College graduate & 0.18 & 0.19 & -0.02 & 0.10 & $0.32^{*}$ \\
& $(0.14)$ & $(0.14)$ & $(0.16)$ & $(0.13)$ & $(0.13)$ \\
\hline Female*College & 0.17 & $0.38^{*}$ & $0.45^{*}$ & 0.30 & 0.00 \\
Graduate & $(0.19)$ & $(0.18)$ & $(0.22)$ & $(0.18)$ & $(0.17)$ \\
\hline Income & $0.07^{*}$ & $0.10^{* *}$ & -0.01 & 0.04 & $0.06^{*}$ \\
& $(0.03)$ & $(0.03)$ & $(0.03)$ & $(0.03)$ & $(0.03)$ \\
\hline Age & $-0.05^{*}$ & $-0.07^{* *}$ & $-0.07^{* *}$ & -0.01 & $-0.05^{*}$ \\
& $(0.02)$ & $(0.02)$ & $(0.03)$ & $(0.02)$ & $(0.02)$ \\
\hline Party & 0.0002 & -0.02 & -0.04 & 0.02 & -0.004 \\
& $(0.03)$ & $(0.03)$ & $(0.02)$ & $(0.03)$ & $(0.03)$ \\
\hline Pocketbook & 0.11 & $0.19^{*}$ & $0.20^{*}$ & $0.17^{*}$ & $0.30^{* *}$ \\
Economic & $(0.08)$ & $(0.07)$ & $(0.09)$ & $(0.07)$ & $(0.07)$ \\
\hline Prospective & $0.47^{* *}$ & $0.22^{*}$ & $0.35^{* *}$ & $0.21^{*}$ & $0.30^{* *}$ \\
Sociotropic Outlook & $(0.09)$ & $(0.09)$ & $(0.10)$ & $(0.09)$ & $(0.08)$ \\
\hline Trade Knowledge & 0.02 & -0.02 & -0.07 & 0.07 & -0.08 \\
& $(0.06)$ & $(0.06)$ & $(0.07)$ & $(0.06)$ & $(0.05)$ \\
\hline Constant & 0.23 & -0.30 & 0.04 & 0.36 & -0.02 \\
& $(0.23)$ & $(0.22)$ & $(0.25)$ & $(0.22)$ & $(0.21)$ \\
\hline Observations & 775 & 789 & 793 & 786 & 767 \\
\hline Stand & & & & \\
\hline
\end{tabular}

Standard errors in parentheses; ${ }^{* *} \mathrm{p}<0.01,{ }^{*} \mathrm{p}<0.05,+\mathrm{p}<0.10$ 
Table 2 - Individual Attitudes Toward Free Trade and Its Components in Six Latin American Countries, 2006: Ordered Probit

\begin{tabular}{|c|c|c|c|c|c|c|}
\hline & & Consumption & & Economic Secu & & \\
\hline & Free & & & Demand for & & \\
\hline & Trade & Consumer & Jobs & Goods & Markets & Growth \\
\hline Female & 0.001 & $-0.24 *$ & $-0.24^{*}$ & -0.04 & $-0.23^{*}$ & 0.09 \\
\hline & 0.12 & 0.11 & 0.11 & 0.11 & 0.11 & 0.12 \\
\hline Age & 0.0004 & 0.01 & $0.01 *$ & $0.01 *$ & 0.01 & -0.01 \\
\hline & 0.004 & 0.004 & 0.004 & 0.004 & 0.004 & 0.005 \\
\hline Education & 0.02 & $0.24 * *$ & $0.10+$ & 0.02 & 0.02 & $-0.16^{*}$ \\
\hline & 0.06 & 0.06 & 0.06 & 0.06 & 0.06 & 0.07 \\
\hline Income & $0.06+$ & 0.04 & 0.03 & 0.02 & $0.07^{*}$ & -0.03 \\
\hline & 0.04 & 0.03 & 0.03 & 0.03 & 0.03 & 0.04 \\
\hline Business & & & & & & \\
\hline Dummy & $0.29 *$ & $0.26^{*}$ & 0.14 & 0.19 & 0.06 & -0.23 \\
\hline & 0.13 & 0.12 & 0.12 & 0.12 & 0.12 & 0.14 \\
\hline Prospective & & & & & & \\
\hline Economic & $0.24 * *$ & $0.18 * *$ & $0.18 * *$ & $0.20 * *$ & $0.25 * *$ & -0.05 \\
\hline Outlook & 0.07 & 0.06 & 0.06 & 0.06 & 0.06 & 0.07 \\
\hline Left Party & & & & & & \\
\hline Dummy & $-0.55^{* *}$ & -0.01 & $0.23 *$ & 0.05 & 0.11 & -0.07 \\
\hline & 0.11 & 0.11 & 0.11 & 0.11 & 0.11 & 0.12 \\
\hline Observations & 523 & 523 & 520 & 515 & 515 & 523 \\
\hline
\end{tabular}

Standard errors in parentheses; ${ }^{* *} \mathrm{p}<0.01,{ }^{*} \mathrm{p}<0.05,+\mathrm{p}<0.10$ 
Table 3 - Individual Attitudes Toward International Trade and Its Effects in Five Predominantly Muslim Countries, 2007: Probit Analysis

\begin{tabular}{|c|c|c|c|c|c|c|c|}
\hline & & Consumption & \multicolumn{4}{|c|}{ Economic Security } & Other \\
\hline & Trade & Consumer & $\begin{array}{c}\text { Job } \\
\text { Security }\end{array}$ & $\begin{array}{c}\text { Job } \\
\text { Creation }\end{array}$ & $\begin{array}{l}\text { Standard of } \\
\text { Living }\end{array}$ & $\begin{array}{l}\text { Domestic } \\
\text { Business }\end{array}$ & $\begin{array}{c}\text { Environ } \\
\text {-ment }\end{array}$ \\
\hline Female & $\begin{array}{c}0.11 \\
(0.09)\end{array}$ & $\begin{array}{c}0.09 \\
(0.09)\end{array}$ & $\begin{array}{c}0.02 \\
(0.09)\end{array}$ & $\begin{array}{c}0.06 \\
(0.09)\end{array}$ & $\begin{array}{c}0.07 \\
(0.09)\end{array}$ & $\begin{array}{l}0.31 * * \\
(0.09)\end{array}$ & $\begin{array}{c}0.11 \\
(0.08)\end{array}$ \\
\hline $\begin{array}{l}\text { College } \\
\text { Graduate }\end{array}$ & $\begin{array}{l}0.59 * * \\
(0.16)\end{array}$ & $\begin{array}{c}0.14 \\
(0.16)\end{array}$ & $\begin{array}{c}0.22 \\
(0.15)\end{array}$ & $\begin{array}{l}0.34^{*} \\
(0.15)\end{array}$ & $\begin{array}{c}0.26 \\
(0.16)\end{array}$ & $\begin{array}{c}0.57 * * \\
(0.16)\end{array}$ & $\begin{array}{c}0.25 \\
(0.14)\end{array}$ \\
\hline $\begin{array}{l}\text { Female* } \\
\text { College } \\
\text { Graduate }\end{array}$ & $\begin{array}{l}-0.42+ \\
(0.24)\end{array}$ & $\begin{array}{l}-0.12 \\
(0.24)\end{array}$ & $\begin{array}{c}0.09 \\
(0.23)\end{array}$ & $\begin{array}{l}-0.04 \\
(0.23)\end{array}$ & $\begin{array}{c}0.13 \\
(0.24)\end{array}$ & $\begin{array}{l}-0.45+ \\
(0.24)\end{array}$ & $\begin{array}{c}0.03 \\
(0.22)\end{array}$ \\
\hline Age & $\begin{array}{c}0.004 \\
(0.003)\end{array}$ & $\begin{array}{c}0.01 \\
(0.003)\end{array}$ & $\begin{array}{c}0.01^{*} \\
(0.003)\end{array}$ & $\begin{array}{c}0.002 \\
(0.003)\end{array}$ & $\begin{array}{c}0.003 \\
(0.003)\end{array}$ & $\begin{array}{c}0.04 \\
(0.003)\end{array}$ & $\begin{array}{l}0.01^{* *} \\
(0.003)\end{array}$ \\
\hline Income & $\begin{array}{l}0.12 * \\
(0.06)\end{array}$ & $\begin{array}{l}0.13^{*} \\
(0.06)\end{array}$ & $\begin{array}{c}0.03 \\
(0.06)\end{array}$ & $\begin{array}{c}0.06 \\
(0.06)\end{array}$ & $\begin{array}{l}0.13^{*} \\
(0.06)\end{array}$ & $\begin{array}{l}-0.01 \\
(0.06)\end{array}$ & $\begin{array}{l}-0.005 \\
(0.05)\end{array}$ \\
\hline Muslim & $\begin{array}{c}-0.59 * * \\
(0.11)\end{array}$ & $\begin{array}{l}-0.18 \\
(0.12)\end{array}$ & $\begin{array}{c}-0.81 * * \\
(0.11)\end{array}$ & $\begin{array}{c}-0.62 * * \\
(0.11)\end{array}$ & $\begin{array}{c}-0.52 * * \\
(0.11)\end{array}$ & $\begin{array}{c}-0.86 * * \\
(0.11)\end{array}$ & $\begin{array}{c}-0.61 * * \\
(0.10)\end{array}$ \\
\hline Constant & $\begin{array}{l}0.46^{* *} \\
(0.17)\end{array}$ & $\begin{array}{c}0.93 * * \\
(0.18)\end{array}$ & $\begin{array}{c}0.02 \\
(0.17)\end{array}$ & $\begin{array}{c}0.20 \\
(0.17)\end{array}$ & $\begin{array}{c}0.49 * * \\
(0.17)\end{array}$ & $\begin{array}{l}0.37 * \\
(0.17)\end{array}$ & $\begin{array}{l}-0.07 \\
(0.16)\end{array}$ \\
\hline $\mathrm{N}$ of Obs & 3,341 & 3,186 & 3,107 & 3,266 & 3,099 & 3,269 & 3,152 \\
\hline
\end{tabular}

Standard errors in parentheses; ${ }^{* *} \mathrm{p}<0.01,{ }^{*} \mathrm{p}<0.05,+\mathrm{p}<0.10$ 


\section{Appendix A - Survey Questions}

\section{U.S. Survey}

The general question reads:

1) As you may know, international trade has increased a great deal in recent years. Do you think that the growth in international trade has made things better or made things worse for the United States as a whole?

The trade effects questions use the same root as the general question, but replace the underlined with the following:

2) ...for you personally?

3) ... for American workers?

4) ...for American business?

5) ...for consumers in the U.S.?

\section{$\underline{\text { Latin America Survey }}$}

1) In general, do you think that free trade is very good, good, bad or very bad for the economy of your country?"

2) Rate the effect of trade on the availability of jobs.

3) Rate the effect of trade on economic growth.

4) Rate the effect of trade on the demand for your country's goods.

5) Rate the effect of trade on the markets for the exports of your country's goods.

Consumer questions:

6) Rate the effect of trade on prices for goods and services.

7) Rate the effect of trade on quality of goods and services.

8) Rate the effect of trade on the variety of goods and services that are available.

\section{Muslim-Country Survey}

1) Do you think international trade is good or bad for creating jobs in [country]?

2) Do you think international trade is good or bad for job security for [country] workers?

3) Do you think international trade is good or bad for [country] economy?

4) Do you think international trade is good or bad for [country] companies?

5) Do you think international trade is good or bad for your own standard of living?

6) Do you think international trade is good or bad for consumers like you?

7) Do you think international trade is good or bad for the environment? 
Appendix B - Disaggregated Consumer Effects for Latin America

Table 4 - Individual Attitudes Toward Free Trade and Components of Consumption in Six Latin American Countries, 2006

\begin{tabular}{|c|c|c|c|}
\hline & Prices & Quality & Variety \\
\hline \multirow[t]{2}{*}{ Gender Dummy } & $-0.27 *$ & $-0.28 *$ & -0.04 \\
\hline & 0.12 & 0.12 & 0.12 \\
\hline \multirow[t]{2}{*}{ Age } & 0.002 & 0.002 & 0.01 \\
\hline & 0.004 & 0.01 & 0.01 \\
\hline \multirow[t]{2}{*}{ Education } & $0.28^{* *}$ & $0.20 * *$ & $0.17^{*}$ \\
\hline & 0.07 & 0.07 & 0.07 \\
\hline \multirow[t]{2}{*}{ Income } & 0.004 & $0.07+$ & 0.03 \\
\hline & 0.04 & 0.04 & 0.04 \\
\hline \multirow[t]{2}{*}{ Business Dummy } & $0.29 *$ & 0.09 & $0.31 *$ \\
\hline & 0.13 & 0.13 & 0.13 \\
\hline \multirow[t]{2}{*}{ Manufacturing Dummy } & -0.13 & -0.04 & -0.22 \\
\hline & 0.27 & 0.27 & 0.27 \\
\hline Prospective Economic & $0.17^{* *}$ & $0.14^{*}$ & $0.15^{*}$ \\
\hline Outlook & 0.07 & 0.07 & 0.07 \\
\hline \multirow[t]{2}{*}{ Left Party Dummy } & 0.11 & -0.15 & -0.08 \\
\hline & 0.12 & 0.12 & 0.12 \\
\hline Sovereignty for & $0.39 * *$ & $0.27^{*}$ & $0.28^{*}$ \\
\hline Investment & 0.11 & 0.11 & 0.11 \\
\hline Observations & 523 & 523 & 523 \\
\hline
\end{tabular}




\section{DAVIDSON INSTITUTE WORKING PAPER SERIES - Most Recent Papers}

The entire Working Paper Series may be downloaded free of charge at: www.wdi.umich.edu

CURRENT AS OF $1 / 17 / 14$

\begin{tabular}{|c|c|c|}
\hline $\begin{array}{c}\text { Publication } \\
\end{array}$ & Authors & Date \\
\hline $\begin{array}{l}\text { No. 1067: Economic (In)Security And Gender Differences In Trade Policy } \\
\text { Attitudes }\end{array}$ & $\begin{array}{l}\text { Jeffrey Drope and } \\
\text { Abdur Chowdhury }\end{array}$ & Jan 2014 \\
\hline $\begin{array}{l}\text { No. 1066: Do business groups help or hinder technological progress in } \\
\text { emerging markets? Evidence from India }\end{array}$ & $\begin{array}{l}\text { Sumon K. Bhaumik and } \\
\text { Ying Zhou }\end{array}$ & Jan 2014 \\
\hline $\begin{array}{l}\text { No. 1065: Fiscal Imbalances and Current Account Adjustments } \\
\text { in the European Transition Economies }\end{array}$ & Rajmund Mirdala & Nov 2013 \\
\hline $\begin{array}{l}\text { No. 1064: Real Output and Prices Adjustments Under Different Exchange } \\
\text { Rate Regimes }\end{array}$ & Rajmund Mirdala & Nov 2013 \\
\hline $\begin{array}{l}\text { No. 1063: The Distribution Dynamics of Income in Central and Eastern } \\
\text { Europe relative to the EU: A Nonparametric Analysis }\end{array}$ & $\begin{array}{l}\text { Nickolay Nenovsky \& } \\
\text { Kiril Tochkov }\end{array}$ & Nov 2013 \\
\hline $\begin{array}{l}\text { No. 1062: Reactions to shocks and monetary policy regimes: inflation } \\
\text { targeting versus flexible currency board in Ghana, South Africa and the } \\
\text { WAEMU }\end{array}$ & $\begin{array}{l}\text { Fadia Al Hajj' Gilles Dufrénot, } \\
\text { Kimiko Sugimoto, Romain Wolf }\end{array}$ & Nov 2013 \\
\hline No. 1061: Distribution Dynamics of Russian Regional Prices & Konstantin Gluschenko & Oct 2013 \\
\hline $\begin{array}{l}\text { No. 1060: Institutional Polycentrism, Entrepreneurs' Social Networks, And } \\
\text { New Venture Growth }\end{array}$ & $\begin{array}{l}\text { Bat Batjargal, Michael Hitt, Anne } \\
\text { Tsui, Jean-Luc Arregle, Justin } \\
\text { Webb and Toyah Miller }\end{array}$ & Sept. 2013 \\
\hline No. 1059: Price Jumps on European Stock Markets & $\begin{array}{l}\text { Jan Hanousek, Evžen Kočenda, } \\
\text { and Jan Novotný }\end{array}$ & Sept. 2013 \\
\hline $\begin{array}{l}\text { No. 1058: Lessons Learned from Tax vs. Expenditure Based Fiscal } \\
\text { Consolidation in the European Transition Economies }\end{array}$ & Rajmund Mirdala & Sept. 2013 \\
\hline $\begin{array}{l}\text { No. 1057: Structural Reforms and Growth in Transition: } \\
\text { A Meta-Analysis }\end{array}$ & Jan Babecky and Tomas Havranek & Aug 2013 \\
\hline No. 1056: Cross-Country Heterogeneity in Intertemporal Substitution & $\begin{array}{l}\text { Tomas Havranek, Roman } \\
\text { Horvath, Zuzana Irsova } \\
\text { \& Marek Rusnak }\end{array}$ & Aug 2013 \\
\hline $\begin{array}{l}\text { No. 1055: Is women's ownership of land a panacea in developing } \\
\text { countries? Evidence from land-owning farm households in Malawi }\end{array}$ & $\begin{array}{l}\text { Sumon K. Bhaumik, Ralitza } \\
\text { Dimova \& Ira N. Gang }\end{array}$ & Aug 2013 \\
\hline No. 1054: Specialization, gravity, and European trade in final goods & $\begin{array}{l}\text { Richard Frensch, Jan Hanousek } \\
\text { and Evzen Kocenda }\end{array}$ & July 2013 \\
\hline $\begin{array}{l}\text { No. 1053: Public Debt Sustainability in Africa: Building Resilience and } \\
\text { Challenges Ahead }\end{array}$ & $\begin{array}{l}\text { Zuzana Brixiova and } \\
\text { Mthuli Ncube }\end{array}$ & July 2013 \\
\hline $\begin{array}{l}\text { No. 1052: YOUTH EMPLOYMENT IN AFRICA: NEW EVIDENCE AND POLICIES } \\
\text { FROM SWAZILAND }\end{array}$ & $\begin{array}{l}\text { Zuzana Brixiova and Thierry } \\
\text { Kangoye }\end{array}$ & June 2013 \\
\hline No. 1051: Oil Windfalls, Fiscal Policy and Money Market Disequilibrium & $\begin{array}{l}\text { Salman Huseynov, Vugar } \\
\text { Ahmadov }\end{array}$ & June 2013 \\
\hline No. 1050: Price Jump Indicators: Stock Market Empirics During the Crisis & $\begin{array}{l}\text { Jan Novotný, Jan Hanousek, and } \\
\text { Evžen Kočenda }\end{array}$ & June 2013 \\
\hline $\begin{array}{l}\text { No. 1049: Impact of Financial Deregulation on Monetary \& Economic } \\
\text { Policy in the Czech Republic, Hungary and Poland: } 1990-2003\end{array}$ & Patricia McGrath & May 2013 \\
\hline
\end{tabular}

